\title{
Nickel-based Catalyst Precursor Prepared Via Microwave-induced Combustion Method: Thermodynamics of Synthesis and Performance in Dry Reforming of $\mathrm{CH}_{4}$
}

\author{
Braulio Silva Barros $^{a *}$, Joanna Kulesza ${ }^{b}$, Dulce Maria de Araújo Meloc, Alain Kienneman ${ }^{d}$ \\ ${ }^{a}$ Escola de Ciências e Tecnologia, Universidade Federal do Rio Grande do Norte - UFRN, \\ Campus Universitário - Lagoa Nova, CEP 59072-970, Natal, RN, Brazil \\ ${ }^{b}$ Departamento de Quimica Fundamental, Universidade Federal de Pernambuco - UFPE, \\ Av. Prof. Moraes Rego, 1235, Cidade Universitária, CEP 50670-901, Recife, PE, Brazil \\ 'Instituto de Química, Universidade Federal do Rio Grande do Norte - UFRN, Campus Universitário - \\ Lagoa Nova, CEP 59072-970, Natal, RN, Brazil \\ ${ }^{d}$ Laboratoire de Matériaux, Surfaces et Procédés pour la Catalyse - LMSPC, Université de Strasbourg, \\ 25 rue Becquerel, 67087, Strasbourg Cedex 02, France
}

Received: March 29, 2015; Revised: June 22, 2015

\begin{abstract}
Nickel-based catalyst precursor for dry reforming of methane was successfully prepared by a self-combustion method. Three different amino acids: urea, glycine and citric acid were tested as fuels in the redox reaction with metal nitrates. For each fuel, a thermodynamic modeling of the combustion reaction was performed. The samples were characterized by X-ray diffraction (XRD), Thermogravimetric analysis (TG), Scanning electron microscopy (SEM), Attenuated total reflectance - Fourier transform infrared (ATR-FTIR) spectroscopy and Temperature-programmed reduction (TPR). XRD data confirmed the presence of several crystalline phases in the as-prepared powders. The sample prepared with citric acid showed very low crystallinity when compared to the other samples. It was found that the heat release rate of the self-combustion is the determinant factor of the crystallization, and it is fuel dependent. SEM results suggest that the distribution and average particle size of as-prepared powders can be controlled by the appropriate selection of the fuel. Further calcination of these samples at $800{ }^{\circ} \mathrm{C} / 4 \mathrm{~h}$ led to the crystallization of perovskite-type structure $\mathrm{LaNiO}_{3}$. Nanostructured $\mathrm{Ni}^{\circ} / \mathrm{La}_{2} \mathrm{O}_{3}$ obtained after reduction of $\mathrm{LaNiO}_{3}$ precursor showed high catalytic activity in dry reforming of methane.
\end{abstract}

Keywords: self-combustion, microwaves, perovskite, amino acids, catalysts

\section{Introduction}

Nickel-based solid catalysts have been used for decades in hydrogen production via steam reforming of natural gas due to their high catalytic activity and low cost, which offer significant technical and economic benefits ${ }^{1,2}$. Beyond the steam reforming ${ }^{1}$, nickel-based catalysts can be applied in other hydrogen production processes such as partial oxidation ${ }^{2}$ or dry and autothermal reforming of methane $e^{3,4}$. These catalysts are usually composed of an active species, such as metallic nickel, which is deposited on the surface of oxide particles via a wet impregnation method. However, this technique does not promote a good dispersion of the active species. A more effective way to achieve a good dispersion of the active species is to use a well-defined crystalline structure as a catalyst precursor.

Mixed oxides with the perovskite-type structure have been extensively investigated regarding this purpose ${ }^{5-7}$. For example, lanthanum nickelate $\left(\mathrm{LaNiO}_{3}\right)$ can be easily reduced by hydrogen or other reducing agent, even methane, to form a nickel-supported catalyst $\left(\mathrm{Ni} / \mathrm{La}_{2} \mathrm{O}_{3}\right)$. In this case, metallic nickel is well dispersed on the surface of lanthanum oxide particles.

*e-mail: brauliobarros@ect.ufrn.br
Commonly, mixed oxides are synthesized in a solid-state reaction where simple metal oxides are mixed and calcined at high temperatures for extended periods of time ${ }^{8,9}$. Although very simple, this method has several drawbacks, such as high power demand due to the high temperature of the reaction, large particle size and little homogeneity of the prepared materials. Most recently other chemical methods have been reported such as sol-gel ${ }^{10}$ Pechini $^{11}$, co-precipitation ${ }^{12}$ and self-combustion ${ }^{13}$.

The self-combustion method has been used to prepare several inorganic compounds, including mixed oxides with perovskite-like structure ${ }^{3,14-16}$. This process involves a redox reaction between metallic salts of interest (oxidizing agents) and an amino-acid "fuel" (reducing agent). The amount of each reactant is defined according to the concepts of the propellant chemistry ${ }^{16,17}$. The total potentials of reduction and oxidation are balanced to promote the maximum release of energy in the reaction and the required heat to start the self-combustion of the precursor solution may be generated by microwaves. In this way, the greater rate and uniformity of heating are achieved which significantly affects the cost reduction in terms of energy and time $e^{3,18,19}$. 
In this paper, we present the synthesis and characterization of $\mathrm{LaNiO}_{3}$ catalyst precursor obtained by a microwave-induced self-combustion method. The effect of the type of the amino acid "fuel" on the crystal structure and microstructure of the prepared samples was studied. Furthermore, the catalytic activity of $\mathrm{Ni}^{0} / \mathrm{La}_{2} \mathrm{O}_{3}$ catalyst derived from reduced $\mathrm{LaNiO}_{3}$ precursor was evaluated.

\section{Experimental Procedures}

The presented studies involve the synthesis and characterization of three nickel-based catalyst precursors prepared by using three different amino acids as fuel (glycine, urea and citric acid). Based on the concepts used in propellant chemistry, $10 \mathrm{mmol}$ each of $\mathrm{La}\left(\mathrm{NO}_{3}\right)_{3} \cdot 6 \mathrm{H}_{2} \mathrm{O}$ and $\mathrm{Ni}\left(\mathrm{NO}_{3}\right)_{2} \cdot 6 \mathrm{H}_{2} \mathrm{O}$ were dissolved in a Pyrex glass beaker using a minimum volume of distilled water. Subsequently, an appropriate amount of amino acid "fuel" was added to the nitrate solution: $27.8 \mathrm{mmol}$ of glycine (sample LNG), $41.7 \mathrm{mmol}$ of urea (sample LNU) or $17.8 \mathrm{mmol}$ of citric acid (sample LNC). The metal nitrates were purchased from MERCK, while glycine, urea and citric acid were acquired from Aldrich, Synth and Vetec, respectively. The solution was kept under constant stirring at about $60{ }^{\circ} \mathrm{C}$. Afterward, the beaker containing the solution was heated in a conventional microwave oven with output power of $800 \mathrm{~W}$ and frequency of $2.45 \mathrm{GHz}$ until the spontaneous ignition.

The as-prepared powders were characterized by X-ray Diffraction (XRD) in a D8 Advance BRUKER apparatus using $\mathrm{Cu} \mathrm{K} \alpha$ radiation $(\lambda=1.5406 \AA$ ), $40 \mathrm{kV}$ and $30 \mathrm{~mA}$. Rietveld refinement analysis was performed by using MAUD 2.53 (Material Analysis Using Diffraction) program package $^{20}$. Scanning Electron Microscopy (SEM) images were recorded using a Philips XL-30 ESEM microscope. Thermogravimetric Analyzes (TGA) were performed on a Shimadzu DTG-60H apparatus under a continuous air flow atmosphere. ATR-FTIR experiments were carried out on a Bruker Vertex 70 spectrometer.

After calcination at $800{ }^{\circ} \mathrm{C}$ for $4 \mathrm{~h}$, the powders were re-characterized by XRD. The reducibility of a selected sample (LNU) was determined by Temperature-Programmed Reduction (TPR) performed on $50 \mathrm{mg}$ of calcined powder, in a flow of reductive gas mixture $\left(\mathrm{H}_{2}=2 \mathrm{ml} \mathrm{min} \mathrm{ma}^{-1}\right.$ and $\left.=36 \mathrm{ml} \mathrm{min}^{-1}\right)$, using a temperature ramp from 25 to $900{ }^{\circ} \mathrm{C}$.

Dry reforming of methane was carried out using $50 \mathrm{mg}$ of catalyst in a fixed-bed quartz reactor (internal diameter of $6.6 \mathrm{~mm}$ ). The operating conditions were set as follows: inlet temperature from 500 to $800{ }^{\circ} \mathrm{C}$; feed flow rates under normal conditions: $\mathrm{Ar}=40 \mathrm{ml} \mathrm{min}{ }^{-1}, \mathrm{CH}_{4}=5 \mathrm{ml} \mathrm{min}^{-1}$ and $\mathrm{CO}_{2}=5 \mathrm{ml} \mathrm{min}^{-1}\left(\mathrm{CH}_{4} / \mathrm{CO}_{2}=1\right)$. The outlet gas was analyzed by means of two gas chromatograph units used simultaneously: the first one equipped with a molecular sieve column and the second one having a HayeSep column. Before testing,

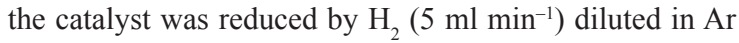
$(40 \mathrm{ml} \mathrm{min}-1)$ at a constant heating rate of $3{ }^{\circ} \mathrm{C} \mathrm{min}^{-1}$ from room temperature to $700{ }^{\circ} \mathrm{C}$, and this temperature was kept stable for $1 \mathrm{~h}$. Subsequently, the flow rate of $\mathrm{H}_{2}$ was cut, and the $\mathrm{CH}_{4} / \mathrm{CO}_{2}$ mixture added. The catalytic performance was evaluated by $\mathrm{CH}_{4}$ and $\mathrm{CO}_{2}$ conversions and $\mathrm{H}_{2} / \mathrm{CO}$ molar ratio calculated as follows:

$$
\begin{aligned}
& \text { Conversion }\left(\mathrm{CH}_{4}\right)(\%)=\frac{\left(\mathrm{CH}_{4}\right)_{\text {in }}-\left(\mathrm{CH}_{4}\right)_{\text {out }}}{\left(\mathrm{CH}_{4}\right)_{\text {in }}} \\
& \text { Conversion }\left(\mathrm{CO}_{2}\right)(\%)=\frac{\left(\mathrm{CO}_{2}\right)_{\text {in }}-\left(\mathrm{CO}_{2}\right)_{\text {out }}}{\left(\mathrm{CO}_{2}\right)_{\text {in }}} \\
& \text { Molar ratio }\left(\mathrm{H}_{2} / \mathrm{CO}\right)=\frac{\left(\mathrm{H}_{2}\right)_{\text {produced }}}{(\mathrm{CO})_{\text {produced }}}
\end{aligned}
$$

\section{Results and Discussion}

Redox type reactions (self-combustion) are usually exothermic and often lead to an explosion if not adequately controlled. Huge amount of gas was released slowly during the reaction when citric acid was used as fuel. On the other hand, when urea was used, the self-combustion of the precursor solution started after 5 minutes of heating exhibiting an intense yellow flame for few seconds. The reaction with glycine as fuel showed an explosive characteristic with an abrupt increase of pressure in the cavity of the microwave oven. This feature of glycine is related to its decomposition in a single event occuring at about $260-280{ }^{\circ} \mathrm{C}$, releasing all energy in a short period. On the other hand, citric acid and urea decompose within multiple steps. For this reason, a preliminary thermodynamic analysis was performed to predict the behavior of the carried reactions and to compare the effects of different fuels on the reaction temperature and the amount of gas released.

The thermodynamic modeling of the combustion reactions between the oxidizing agents (nitrates of lanthanum and nickel) and a reducing agent (citric acid, urea or glycine) was performed on the basis of the propellant chemistry. All calculations were done-considering a stoichiometric oxidizer/reducer ratio and $\mathrm{N}_{2}, \mathrm{CO}_{2}$ and $\mathrm{H}_{2} \mathrm{O}$ as the principal gaseous products. The involved enthalpy of the reactions and the adiabatic flame temperature were calculated by using thermodynamic data obtained from the literature (see Table 1) and the following equations:

$$
\begin{aligned}
& \Delta H^{0}=\left(\sum n \Delta H_{p}^{0}\right)-\left(n n \Delta H_{r}^{0}\right) \\
& T_{f}=T_{o}+\frac{\Delta H_{r}-\Delta H_{p}}{C_{p}}
\end{aligned}
$$

where $\mathbf{n}$ is the number of moles of each species, $\Delta \mathrm{H}^{0}{ }_{\mathbf{p}}$ and $\Delta \mathrm{H}^{0}{ }_{\mathrm{r}}$ are the standard enthalpies of formation of products and reactants, $\mathbf{C}_{\mathbf{p}}$ is the heat capacity of reaction products at constant pressure, $\mathbf{T}_{\mathbf{f}}$ is the adiabatic flame temperature and $\mathbf{T}_{\mathbf{0}}$ is $298 \mathrm{~K}$.

From a thermodynamic point of view, the combustion reaction between oxidizing and reducing agents may occur in different ways. Table 2 shows the chemical reactions involved and its respective enthalpies. The equations that describe these reactions were chosen based on the reactants and the combustion reaction products obtained in preliminary tests with glycine. Thus, we considered the formation of $\mathrm{LaNiO}_{3}$ or a mixture of $\mathrm{NiO}$ and $\mathrm{La}_{2} \mathrm{NiO}_{4}$.

As it can be observed in Table 2, the combustion reactions of urea (R1), glycine (R2) and citric acid (R3) are exothermic and may provide heat required for the self-combustion 
synthesis. On the other hand, thermal decomposition of nitrates is endothermic and leads to the formation of $\mathrm{NiO}$ (R4) and $\mathrm{La}_{2} \mathrm{O}_{3}(\mathrm{R} 5)$, respectively.

The overall reaction for the combustion synthesis of $\mathrm{LaNiO}_{3}$ may be described by equations RF1 (RI1 + mR1) for urea, RF3 (RI1 + mR2) for glycine and RF5 (RI1 + MR3) for citric acid. However, preliminary tests suggested the formation of $\mathrm{NiO}$ and $\mathrm{La}_{2} \mathrm{NiO}_{4}$ instead of a single phase $\mathrm{LaNiO}_{3}$, what led us to consider another thermodynamic description of these overall reactions. Assuming that $\mathrm{NiO}$ and $\mathrm{La}_{2} \mathrm{NiO}_{4}$ are the solid products, we propose the overall

Table 1. Thermodynamic data: enthalpy and heat capacity ${ }^{21,22}$.

\begin{tabular}{|c|c|c|}
\hline Compound & $\begin{array}{c}\Delta \mathrm{H}_{\mathrm{f}}^{0} \text { at } 25^{\circ} \mathrm{C} \\
\left(\mathrm{kcal} \mathrm{mol}^{-1}\right)\end{array}$ & 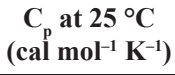 \\
\hline $\mathrm{CO}\left(\mathrm{NH}_{2}\right)_{2(\mathrm{~s})}$ & -79.71 & 22.26 \\
\hline $\mathrm{C}_{2} \mathrm{H}_{5} \mathrm{NO}_{2(\mathrm{~s})}$ & -126.2 & - \\
\hline $\mathrm{C}_{6} \mathrm{H}_{8} \mathrm{O}_{7(\mathrm{~s})}$ & -368.9 & - \\
\hline $\mathrm{Ni}\left(\mathrm{NO}_{3}\right)_{2} \cdot 6 \mathrm{H}_{2} \mathrm{O}(\mathrm{s})$ & -528.6 & 111 \\
\hline $\mathrm{La}\left(\mathrm{NO}_{3}\right)_{3} \cdot 6 \mathrm{H}_{2} \mathrm{O}_{(\mathrm{s})}$ & -732.23 & - \\
\hline $\mathrm{LaNiO}_{3(\mathrm{~s})}$ & -292.8 & 23.51 \\
\hline $\mathrm{La}_{2} \mathrm{NiO}_{4(\mathrm{~s})}$ & -486.7 & 38.8 \\
\hline $\mathrm{La}_{2} \mathrm{O}_{3(\mathrm{~s})}$ & -428.7 & 26 \\
\hline $\mathrm{NiO}_{(\mathrm{s})}$ & -57.3 & 10.59 \\
\hline $\mathrm{H}_{2} \mathrm{O}_{(\mathrm{g})}$ & -57.796 & 8.025 \\
\hline $\mathrm{CO}_{2(\mathrm{~g})}$ & -94.051 & 11.16 \\
\hline $\mathrm{N}_{2(\mathrm{~g})}$ & 0 & 6.8 \\
\hline $\mathrm{O}_{2(\mathrm{~g})}$ & 0 & 7.01 \\
\hline
\end{tabular}

$(\mathrm{s})=$ solid. $(\mathrm{g})=$ gaseous . reactions RF2, RF4 and RF6 when urea, glycine and citric acid are used as fuel, respectively. Based on these data, the enthalpy of combustion, adiabatic flame temperature and the amount of gas released were calculated (Table 3).

The flame temperature is significantly influenced by the type of fuel as well as the fuel/oxidizer ratio and the amount of water remaining in the precursor solution at the moment of the ignition ${ }^{23}$. The adiabatic flame temperatures may reach values higher than $900{ }^{\circ} \mathrm{C}$ for all tested fuels (see Table 3). However, measured flame temperatures are usually lower than calculated values due to the radiation losses, incomplete combustion, air heating, water vaporization, among other factors.

X-ray diffraction patterns of as-prepared powders are shown in Figure 1. It can be seen that the self-combustion reaction led to the crystallization of a mixture of several phases, but no trace of the $\mathrm{LaNiO}_{3}$ perovskite-type structure is observed. The intensity and sharpness of the diffraction peaks suggest the increase of the crystallinity in the following order: $\mathrm{LNC}<\mathrm{LNU}<\mathrm{LNG}$.

Four crystalline phases were identified in the samples prepared with glycine; the primary phase $\mathrm{La}_{2} \mathrm{NiO}_{4}$, with tetragonal $\mathrm{K}_{2} \mathrm{NiF}_{4}$-type structure (JCPDS file $\mathrm{n}^{\circ} 11-0557$ ) and the secondary phases $\mathrm{NiO}$ (JCPDS file $\left.\mathrm{n}^{\circ} 47-1049\right), \mathrm{La}(\mathrm{OH})_{3}$ (JCPDS file $\mathrm{n}^{\circ}$ 6-0585) and metallic nickel (JCPDS file 65-0380). The sample synthesized with urea also exhibited the $\mathrm{La}_{2} \mathrm{NiO}_{4}$ oxide as well as traces of $\mathrm{NiO}, \mathrm{La}(\mathrm{OH})_{3}$ and lanthanum oxynitrates: $\mathrm{LaONO}_{3}$ (JCPDS file $\mathrm{n}^{\circ}$ 23-1149) and $\mathrm{La}_{5} \mathrm{O}_{7} \mathrm{NO}_{3}$ (JCPDS file $\mathrm{n}^{\circ}$ 38-0891).

According to Gobichon et al. ${ }^{24}$ lanthanum oxynitrates such as $\mathrm{LaONO}_{3}, \mathrm{La}_{3} \mathrm{O}_{4} \mathrm{NO}_{3}$ and $\mathrm{La}_{5} \mathrm{O}_{7} \mathrm{NO}_{3}$ are formed during thermal decomposition of lanthanum nitrate over the temperature range $320-470{ }^{\circ} \mathrm{C}$. Thus, the presence of these phases indicates that the heat of combustion generated by

Table 2. Chemical reactions involved in the combustion reaction.

\begin{tabular}{|c|c|c|}
\hline Reaction & Descriptive equation & $\Delta \mathbf{H}^{0}\left(25^{\circ} \mathrm{C}\right) / \mathrm{kcal}$ \\
\hline $\mathrm{R} 1$ & $\mathrm{CO}\left(\mathrm{NH}_{2}\right)_{2}+1.5 \mathrm{O}_{2} \rightarrow \mathrm{CO}_{2}+2 \mathrm{H}_{2} \mathrm{O}+\mathrm{N}_{2}$ & -129.9 \\
\hline $\mathrm{R} 2$ & $\mathrm{NH}_{5} \mathrm{C}_{2} \mathrm{O}_{2}+2.25 \mathrm{O}_{2} \rightarrow 2 \mathrm{CO}_{2}+2.5 \mathrm{H}_{2} \mathrm{O}+0.5 \mathrm{~N}_{2}$ & -206.4 \\
\hline $\mathrm{R} 3$ & $\mathrm{C}_{6} \mathrm{H}_{8} \mathrm{O}_{7}+4.5 \mathrm{O}_{2} \rightarrow 6 \mathrm{CO}_{2}+4 \mathrm{H}_{2} \mathrm{O}$ & -426.5 \\
\hline $\mathrm{R} 4$ & $\mathrm{Ni}\left(\mathrm{NO}_{3}\right)_{2} \cdot 6 \mathrm{H}_{2} \mathrm{O} \rightarrow \mathrm{NiO}+\mathrm{N}_{2}+2.5 \mathrm{O}_{2}+6 \mathrm{H}_{2} \mathrm{O}$ & +124.5 \\
\hline R5 & $\mathrm{La}\left(\mathrm{NO}_{3}\right)_{3} \cdot 6 \mathrm{H}_{2} \mathrm{O} \rightarrow 0.5 \mathrm{La}_{2} \mathrm{O}_{3}+1.5 \mathrm{~N}_{2}+3.75 \mathrm{O}_{2}+6 \mathrm{H}_{2} \mathrm{O}$ & +171.1 \\
\hline R6 & $\mathrm{NiO}+0.5 \mathrm{La}_{2} \mathrm{O}_{3}+0.75 \mathrm{O}_{2} \rightarrow \mathrm{LaNiO}_{3}$ & -21.4 \\
\hline $\mathrm{R} 7$ & $\mathrm{NiO}+\mathrm{La}_{2} \mathrm{O}_{3} \rightarrow \mathrm{La}_{2} \mathrm{NiO}_{4}$ & -0.7 \\
\hline RI1 & $\mathrm{Ni}\left(\mathrm{NO}_{3}\right)_{2} \cdot 6 \mathrm{H}_{2} \mathrm{O}+\mathrm{La}\left(\mathrm{NO}_{3}\right)_{3} \cdot 6 \mathrm{H}_{2} \mathrm{O} \rightarrow \mathrm{LaNiO}_{3}+2.5 \mathrm{~N}_{2}+6 \mathrm{O}_{2}+12 \mathrm{H}_{2} \mathrm{O}$ & +274.5 \\
\hline RI2 & $\mathrm{Ni}\left(\mathrm{NO}_{3}\right)_{2} \cdot 6 \mathrm{H}_{2} \mathrm{O}+\mathrm{La}\left(\mathrm{NO}_{3}\right)_{3} \cdot 6 \mathrm{H}_{2} \mathrm{O} \rightarrow 0.5 \mathrm{La}_{2} \mathrm{NiO}_{4}+0.5 \mathrm{NiO}+2.5 \mathrm{~N}_{2}+6.25 \mathrm{O}_{2}+12 \mathrm{H}_{2} \mathrm{O}$ & +295.3 \\
\hline RF1 & $\begin{array}{l}\mathrm{Ni}\left(\mathrm{NO}_{3}\right)_{2} \cdot 6 \mathrm{H}_{2} \mathrm{O}+\mathrm{La}\left(\mathrm{NO}_{3}\right)_{3} \cdot 6 \mathrm{H}_{2} \mathrm{O}+\boldsymbol{m} \mathrm{CO}\left(\mathrm{NH}_{2}\right)_{2}+(1.5 \boldsymbol{m}-6) \mathrm{O}_{2} \rightarrow \mathrm{LaNiO}_{3}+(12+ \\
2 \boldsymbol{m}) \mathrm{H}_{2} \mathrm{O}+(2.5+\boldsymbol{m}) \mathrm{N}_{2}+\boldsymbol{m} \mathrm{CO}_{2}\end{array}$ & $274.5+\boldsymbol{m}(-129.9)$ \\
\hline RF2 & $\begin{array}{l}\mathrm{Ni}\left(\mathrm{NO}_{3}\right)_{2} \cdot 6 \mathrm{H}_{2} \mathrm{O}+\mathrm{La}\left(\mathrm{NO}_{3}\right)_{3} \cdot 6 \mathrm{H}_{2} \mathrm{O}+\boldsymbol{m} \mathrm{CO}\left(\mathrm{NH}_{2}\right)_{2}+(1.5 \boldsymbol{m}-6.52) \mathrm{O}_{2} \rightarrow 0.5 \mathrm{La}_{2} \mathrm{NiO}_{4}+ \\
0.5 \mathrm{NiO}+(12+2 \boldsymbol{m}) \mathrm{H}_{2} \mathrm{O}+(2.5+\boldsymbol{m}) \mathrm{N}_{2}+\boldsymbol{m} \mathrm{CO}_{2}\end{array}$ & $295.3+\boldsymbol{m}(-129.9)$ \\
\hline RF3 & $\begin{array}{l}\mathrm{Ni}\left(\mathrm{NO}_{3}\right)_{2} \cdot 6 \mathrm{H}_{2} \mathrm{O}+\mathrm{La}\left(\mathrm{NO}_{3}\right)_{3} \cdot 6 \mathrm{H}_{2} \mathrm{O}+\boldsymbol{m} \mathrm{NH}_{5} \mathrm{C}_{2} \mathrm{O}_{2}+(2.25 \boldsymbol{m}-6) \mathrm{O}_{2} \rightarrow \mathrm{LaNiO}_{3}+(12+ \\
2.5 \boldsymbol{m}) \mathrm{H}_{2} \mathrm{O}+(2.5+0.5 \boldsymbol{m}) \mathrm{N}_{2}+2 \boldsymbol{m} \mathrm{CO}_{2}\end{array}$ & $274.5+\boldsymbol{m}(-206.4)$ \\
\hline RF4 & $\begin{array}{l}\mathrm{Ni}\left(\mathrm{NO}_{3}\right)_{2} \cdot 6 \mathrm{H}_{2} \mathrm{O}+\mathrm{La}\left(\mathrm{NO}_{3}\right)_{3} \cdot 6 \mathrm{H}_{2} \mathrm{O}+\boldsymbol{m} \mathrm{NH}_{5} \mathrm{C}_{2} \mathrm{O}_{2}+(2.25 \boldsymbol{m}-6.25) \mathrm{O}_{2} \rightarrow 0.5 \mathrm{La}_{2} \mathrm{NiO}_{4}+ \\
0.5 \mathrm{NiO}+(12+2.5 \boldsymbol{m}) \mathrm{H}_{2} \mathrm{O}+(2.5+0.5 \boldsymbol{m}) \mathrm{N}_{2}+2 \boldsymbol{m} \mathrm{CO}_{2}\end{array}$ & $295.3+\boldsymbol{m}(-206.4)$ \\
\hline RF5 & $\begin{array}{l}\mathrm{Ni}\left(\mathrm{NO}_{3}\right)_{2} \cdot 6 \mathrm{H}_{2} \mathrm{O}+\mathrm{La}\left(\mathrm{NO}_{3}\right)_{3} \cdot 6 \mathrm{H}_{2} \mathrm{O}+\boldsymbol{m} \mathrm{C}_{6} \mathrm{H}_{8} \mathrm{O}_{7}+(4.5 \boldsymbol{m}-6) \mathrm{O}_{2} \rightarrow \mathrm{LaNiO}_{3}+(12+4 \boldsymbol{m}) \\
\mathrm{H}_{2} \mathrm{O}+2.5 \mathrm{~N}_{2}+6 \boldsymbol{m} \mathrm{CO}_{2}\end{array}$ & $274.5+\boldsymbol{m}(-426.5)$ \\
\hline RF6 & $\begin{array}{l}\mathrm{Ni}\left(\mathrm{NO}_{3}\right)_{2} \cdot 6 \mathrm{H}_{2} \mathrm{O}+\mathrm{La}\left(\mathrm{NO}_{3}\right)_{3} \cdot 6 \mathrm{H}_{2} \mathrm{O}+\boldsymbol{m} \mathrm{C}_{6} \mathrm{H}_{8} \mathrm{O}_{7}+(4.5 \boldsymbol{m}-6.25) \mathrm{O}_{2} \rightarrow 0.5 \mathrm{La}_{2} \mathrm{NiO}_{4}+ \\
0.5 \mathrm{NiO}+(12+4 \boldsymbol{m}) \mathrm{H}_{2} \mathrm{O}+2.5 \mathrm{~N}_{2}+6 \boldsymbol{m} \mathrm{CO}_{2}\end{array}$ & $295.3+\boldsymbol{m}(-426.5)$ \\
\hline
\end{tabular}


Table 3. Enthalpy of combustion, adiabatic flame temperature and number of moles of gas released.

\begin{tabular}{cccc}
\hline Reaction & $\begin{array}{c}\text { Enthalpy of } \\
\text { combustion } \\
\text { (kcal/mol) }\end{array}$ & $\begin{array}{c}\text { Adiabatic } \\
\text { flame } \\
\text { temperature } \\
\left({ }^{\circ} \mathbf{C}\right)\end{array}$ & $\begin{array}{c}\text { Number of } \\
\text { moles of gas } \\
\text { released (mol) }\end{array}$ \\
\hline RF1 & -267.2 & 984 & 31.2 \\
RF2 & -246.4 & 926 & 31.2 \\
RF3 & -276.6 & 1092 & 37.4 \\
RF4 & -255.8 & 1032 & 37.4 \\
RF5 & -294.2 & 1118 & 27.8 \\
RF6 & -273.4 & 1037 & 27.8 \\
\hline
\end{tabular}

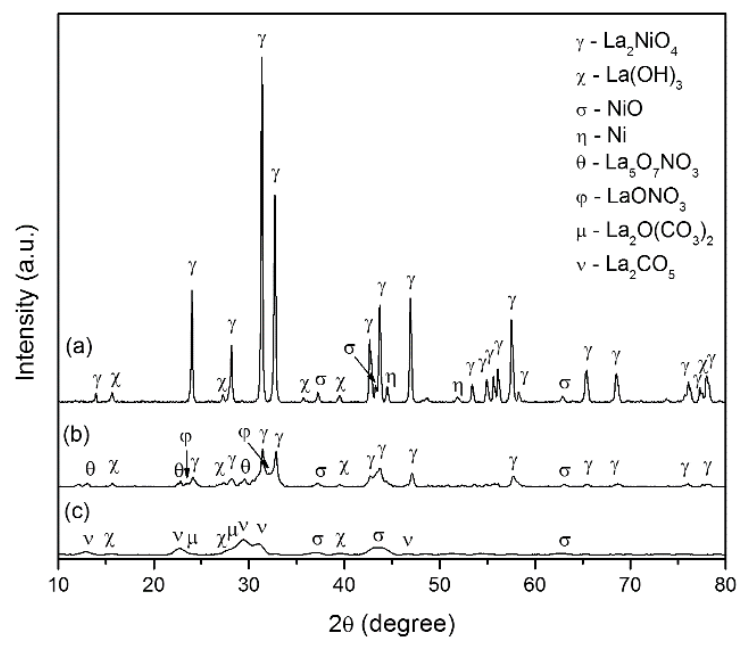

Figure 1. X-ray diffraction patterns of as-prepared samples (a) LNG, (b) LNU and (c) LNC.

urea was not enough to assure the complete decomposition of the metal nitrates and to form the respective oxides. Thermal decomposition of urea is a multiple-step process in which many intermediate compounds are formed, such as $\mathrm{HCNO},(\mathrm{HCNO})_{3}, \mathrm{H}_{2} \mathrm{NCONHCONH}_{2}$, among others.

The formation of $\mathrm{La}_{2} \mathrm{NiO}_{4}$ and $\mathrm{NiO}$ instead of $\mathrm{LaNiO}_{3}$ occurs due to the limited availability of oxygen from the reactants. According to reactions described in Table 2, the oxygen content of the reactants is sufficient to form a mixture of oxides, $\mathrm{La}_{2} \mathrm{NiO}_{4}+\mathrm{NiO}$. On the other hand, the synthesis of $\mathrm{LaNiO}_{3}$ requires the presence of oxygen from the environment.

The XRD pattern of the sample synthesized with citric acid indicates low crystallinity, however it was possible to identify the following crystalline phases: $\mathrm{NiO}, \mathrm{La}(\mathrm{OH})_{3}$, $\mathrm{La}_{2} \mathrm{CO}_{5}$ (JCPDS file $\mathrm{n}^{\circ} 32-0320$ ) and $\mathrm{La}_{2} \mathrm{O}\left(\mathrm{CO}_{3}\right)_{2}$ (JCPDS file $\mathrm{n}^{\circ}$ 32-0490). The presence of lanthanum carbonates may be a consequence of the massive carbon amount released during the thermal decomposition of citric acid.

Figure 2 shows TG curves of as-prepared powders. For all cases, maximum weight loss was reached up to $700{ }^{\circ} \mathrm{C}$ : $7.4,15.5$ and $38.3 \%$ for the samples obtained with glycine, urea and citric acid, respectively. In general, the profile of weight loss curves of the samples prepared with citric acid and

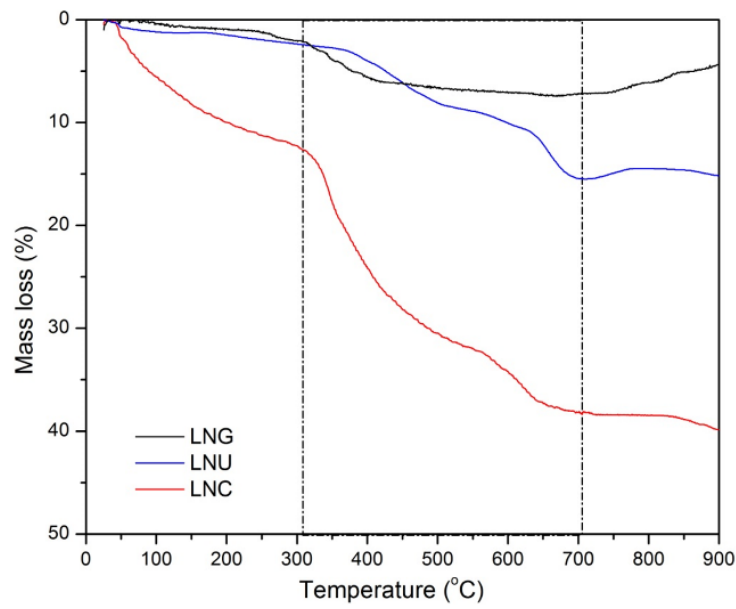

Figure 2. TG curves of the as-synthesized samples prepared by microwave-assisted combustion method using different fuels.

urea is quite similar. In both cases, the first event of weight loss is observed up to $350-400{ }^{\circ} \mathrm{C}$ corresponding probably to adsorbed water and $\mathrm{La}(\mathrm{OH})_{3}$ decomposition. A second event occurring from 400 to $600{ }^{\circ} \mathrm{C}$ may be assigned to the decomposition of the lanthanum oxynitrates. From 600 to $700{ }^{\circ} \mathrm{C}$ the final weight loss event due to the decomposition of lanthanum carbonate species can be seen. Above $700^{\circ} \mathrm{C}$ these samples show a distinguishable behavior; while the sample made with citric acid is stable, the sample prepared with urea shows a slight increase of mass. This weight gain may be ascribed to the oxidation of $\mathrm{Ni}^{2+}$ to $\mathrm{Ni}^{3+}$, which takes place during the crystallization of $\mathrm{LaNiO}_{3}$. For the sample produced by using glycine as fuel, the TG curves revealed two weight loss events found at about $100-250$ and $250-450{ }^{\circ} \mathrm{C}$ corresponding to adsorbed water and $\mathrm{La}(\mathrm{OH})_{3}$ decomposition, respectively. In addition, this sample showed an increase of mass above $750{ }^{\circ} \mathrm{C}$ due to the reaction between $\mathrm{NiO}$ and $\mathrm{La}_{2} \mathrm{NiO}_{4}$ leading to the crystallization of $\mathrm{LaNiO}_{3}$.

Figure 3 depicts the ATR-FTIR spectra of the samples taken in air atmosphere at room temperature. At least three distinct vibrational regions at 3660-3000 (OH stretching), 1700-750 (nitrate/carbonate stretching) and 560-400 $\mathrm{cm}^{-1}$ (metal-oxygen stretching) can be noted. In the range of 1700-1200, the peaks are rather broad, suggesting overlapping of the bands originated from different phases such as nitrates and carbonates. Above $560 \mathrm{~cm}^{-1}$, a significant increase in absorbance is observed ascribed to $\mathrm{La}$ (or Ni)-O stretching vibrations.

Figure 4 shows SEM images of the as-prepared powders. The samples present typical morphology of powders prepared via combustion reaction. Sponge-like agglomerates formed of nanoscale particles are clearly observed, independently of the fuel used. However, the change of fuel promoted the increase in the size of particles in the following order; citric acid (Figures 4a-b), urea (Figures 4c-d) and glycine (Figures $4 \mathrm{e}-\mathrm{f}$ ). The sample formed using citric acid has a higher porosity with respect to urea and glycine, which show pre-sintering. These results are in agreement with the thermodynamic data and the number of moles of gas released (see Table 2). The porosity rises with increasing 


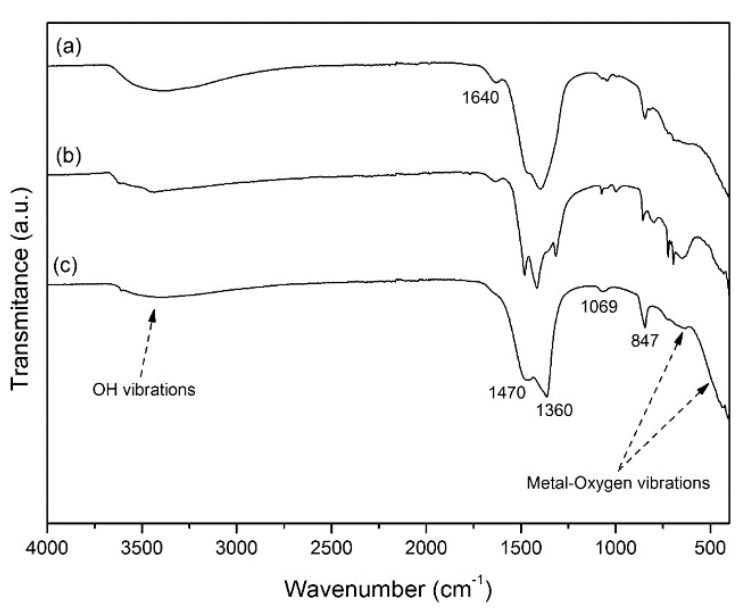

Figure 3. ATR-FTIR spectra of the as-prepared samples by a microwave-assisted combustion method using glycine (a), urea (b) and citric acid (c) as fuel.

the amount of released gas; on the other hand, the increase of the enthalpy of combustion led to sintering of particles.

The particle size distribution was analyzed from SEM images taking into account the longest length of each particle measured, and a histogram is presented in Figure 5. Data were normalized based on the number of particles examined, sixteen for each micrograph. As observed, the sample synthesized with citric acid has a narrow distribution with particles size varying from 100 to $150 \mathrm{~nm}$. In the case of sample LNU (urea as fuel), about $80 \%$ of the particles have sizes ranging from 200 to $300 \mathrm{~nm}$, whereas, when glycine was used as fuel, the sample LNG shows particles size distribution significantly larger, typically $225-475 \mathrm{~nm}$.

The as-prepared powders were calcined at $800^{\circ} \mathrm{C}$ for $4 \mathrm{~h}$ and then analyzed by XRD and the patterns are depicted in Figure 6. As expected, based on TG data, the calcination led to the crystallization of a single phase $\mathrm{LaNiO}_{3}$. All diffraction lines were properly indexed as rhombohedral structure (space group R-3m) according to the JCPDS file $n^{\circ} 33-0711$. However, it must be considered that the mechanism of crystallization may be different from that of sample prepared with citric acid (LNC). This sample showed a significant number of intermediate compounds of the combustion reaction, mainly carbonates, but no traces of oxides were observed. For that reason, crystallization starts with decomposition of these compounds forming simple oxides followed by the diffusion of the atomic species leading to the formation of a mixed oxide $\mathrm{LaNiO}_{3}$. On the other hand, the samples prepared with glycine (LNG) and urea (LNU) presented a significant amount of oxides and just traces of intermediate compounds of the combustion reaction. Therefore, it was found that the perovskite structure crystallizes directly via diffusion of the atomic species.

Temperature-Programmed Reduction (TPR) was carried out to evaluate the reducibility of the perovskite structure prepared by microwave-assisted combustion method. Figure 7a shows the TPR profile of the sample LNU calcined at $800{ }^{\circ} \mathrm{C}$ for $4 \mathrm{~h}$. Two $\mathrm{H}_{2}$ consumption events can be easily distinguished. The first event (I) with a maximum observed at $440{ }^{\circ} \mathrm{C}$ corresponds to the reduction of the $\mathrm{Ni}^{3+}$ to $\mathrm{Ni}^{2+}$ leading to the formation of $\mathrm{La}_{2} \mathrm{Ni}_{2} \mathrm{O}_{5}{ }^{[25]}$. The presence of a left-shoulder assigned to the amorphous or superficial nickel oxide (NiO) is also noticeable ${ }^{3}$. The second $\mathrm{H}_{2}$ consumption peak (II) with a maximum at $570{ }^{\circ} \mathrm{C}$ is related to the reduction of $\mathrm{Ni}^{2+}$ to $\mathrm{Ni}^{0}$. As expected, this event consumes approximately two times more $\mathrm{H}_{2}$ than the first one (see Figure 7a). Above $650{ }^{\circ} \mathrm{C}$ all nickel present in the sample is reduced to metallic form. After the TPR test, the sample was collected and characterized by XRD. Phase composition was estimated by the Rietveld method (see Figure 7b). A good agreement between experimental and calculated curves was obtained, the weighted residual error $\mathrm{R}_{\mathrm{wp}}$ reached $3.64 \%$ and the goodness-of-fit ( $\mathrm{sig}$ ) 1.27. The results confirmed the formation of $29 \%$ of $\mathrm{Ni}^{0}$ and $71 \%$ of $\mathrm{La}_{2} \mathrm{O}_{3}$ (by mass), very close to theoretical values calculated based on perovskite formula $\mathrm{LaNiO}_{3}: 26.4 \%$ of $\mathrm{Ni}^{0}$ and $73.6 \%$ of $\mathrm{La}_{2} \mathrm{O}_{3}$ (by mass). Slight differences in the nickel content are justified by the presence of the amorphous phase $\mathrm{NiO}$, previously proposed based on TPR profile analysis.

The sample LNU was tested as catalyst precursor after being calcined and reduced in $\mathrm{H}_{2}$ stream under the conditions previously established. This procedure allows the formation of a Ni $/ \mathrm{La}_{2} \mathrm{O}_{3}$ catalyst derived from perovskite structure. The activity of this catalyst in dry reforming of methane was evaluated under atmospheric pressure as a function of temperature. The $\mathrm{CH}_{4}$ and $\mathrm{CO}_{2}$ conversions as well as the $\mathrm{H}_{2} / \mathrm{CO}$ molar ratio are presented in Figure 8.

No activity was observed in a low-temperature reaction $\left(500{ }^{\circ} \mathrm{C}\right)$. However, conversions of both $\mathrm{CH}_{4}$ and $\mathrm{CO}_{2}$ reached 85 and $88 \%$ at $800{ }^{\circ} \mathrm{C}$, respectively. These conversion values are in a good agreement with results recently reported by Nain et al. ${ }^{25}$, which were obtained over $\mathrm{LaNiO}_{3}$-based catalysts prepared by nanocasting. It is worth saying that the same authors also reported that these results were much better than those obtained with $\mathrm{LaNiO}_{3}$-based catalysts prepared by a conventional method (citrate process).

The $\mathrm{H}_{2} / \mathrm{CO}$ molar ratio, initially of 0.7 at $550{ }^{\circ} \mathrm{C}$, increases as the temperature rises to $650{ }^{\circ} \mathrm{C}$, reaching the value of 1. This value decreases until 0.9 as the temperature rises from 700 to $800{ }^{\circ} \mathrm{C}$. Based on the stoichiometry of the dry reforming reaction (Equation 6), a value equal to 1 is expected. However, at higher temperatures $\left(650-800{ }^{\circ} \mathrm{C}\right)$, hydrogen can be partially consumed by the reverse Water-Gas Shift Reaction (RWGS) represented in Equation $7^{25,26}$.

$\mathrm{CH}_{4}+\mathrm{CO}_{2}=2 \mathrm{H}_{2}+2 \mathrm{CO}$

$\mathrm{CO}_{2}+\mathrm{H}_{2}=\mathrm{CO}+\mathrm{H}_{2} \mathrm{O}$

It is worth noting that other side-reactions can take place during dry reforming of methane, which may also affect the composition and stoichiometry of the products. Some of them can involve carbon formation. These reactions should be avoided or limited because they lead to the catalyst deactivation. In this way, the effect of a catalyst support with basic characteristics, such as $\mathrm{La}_{2} \mathrm{O}_{3}$, becomes crucial, and it can improve the resistance of coke deposition. 


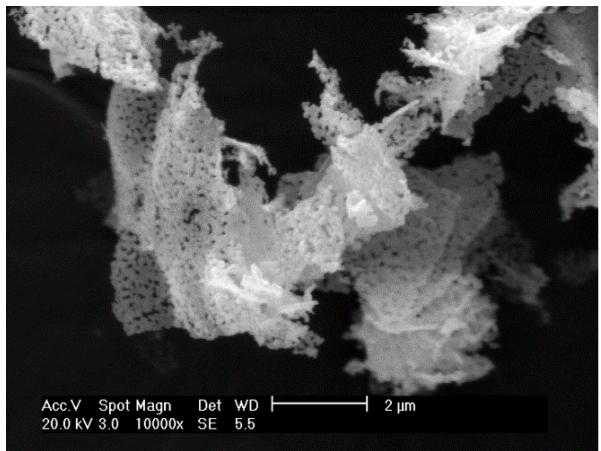

(a)

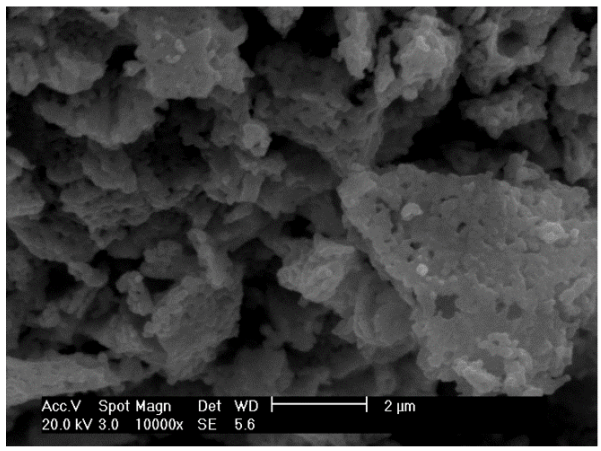

(c)

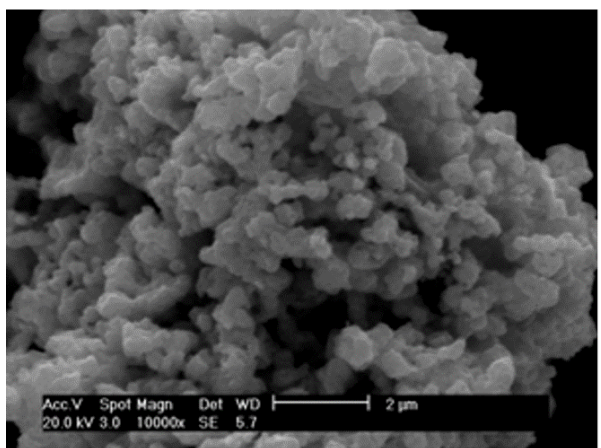

(e)

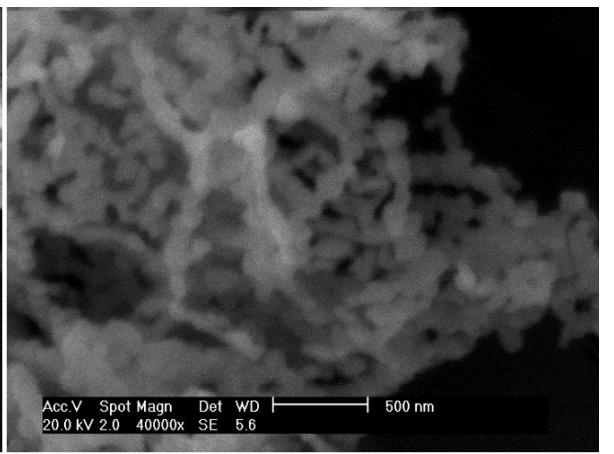

(b)

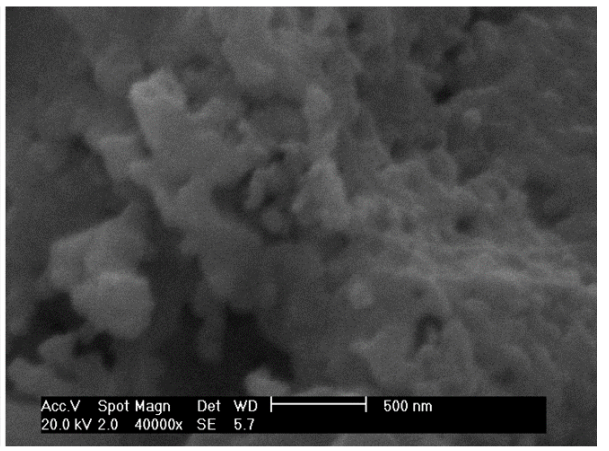

(d)

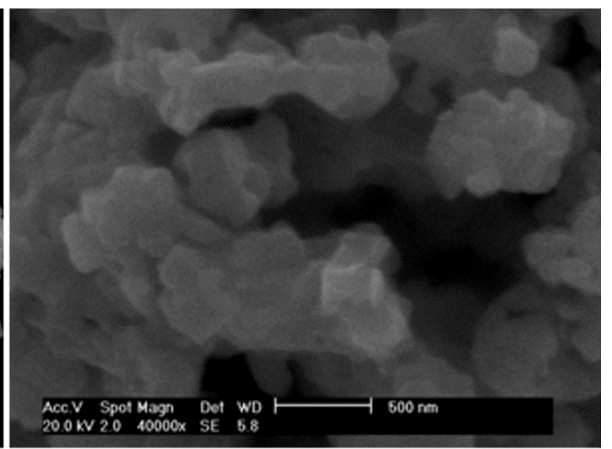

(f)

Figure 4. SEM micrographs of the as-prepared samples by a microwave-induced combustion method using as fuel: citric acid (a-b), urea (c-d) and glycine (e-f). Magnification of 10000x (at left) and 40000x (at right).

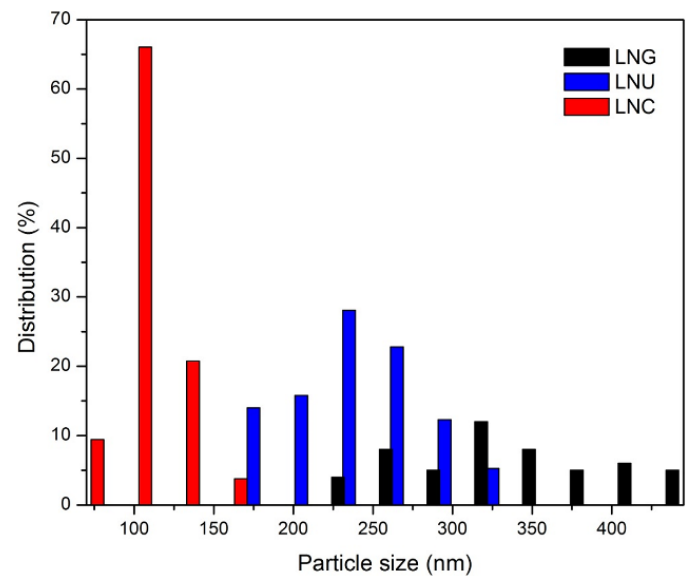

Figure 5. Particles size distribution of as-synthesized samples measured from SEM micrographs.

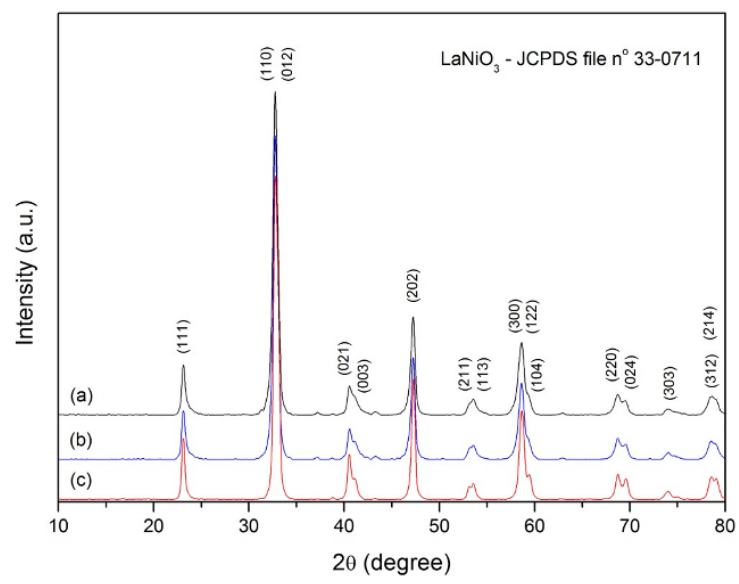

Figure 6. XRD patterns of the samples calcined at $800^{\circ} \mathrm{C}$ for $4 \mathrm{~h}$ : (a) LNG, (b) LNU and (c) LNC. 


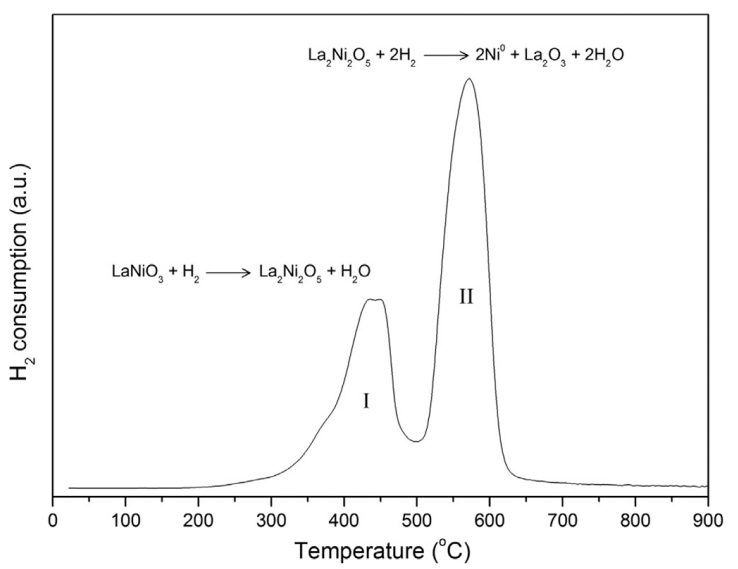

(a)

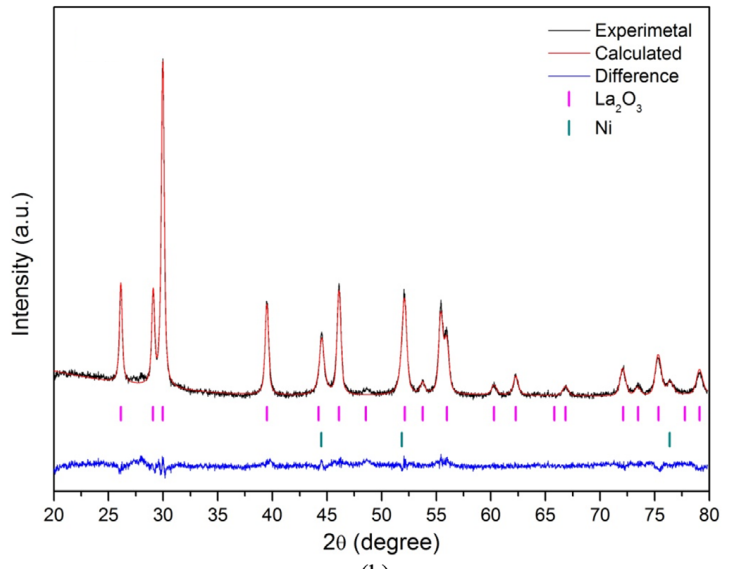

(b)

Figure 7. TPR profile of the sample LNU calcined at $800{ }^{\circ} \mathrm{C}$ for $4 \mathrm{~h}$ (a) and Rietveld refinement profile after reduction (b).

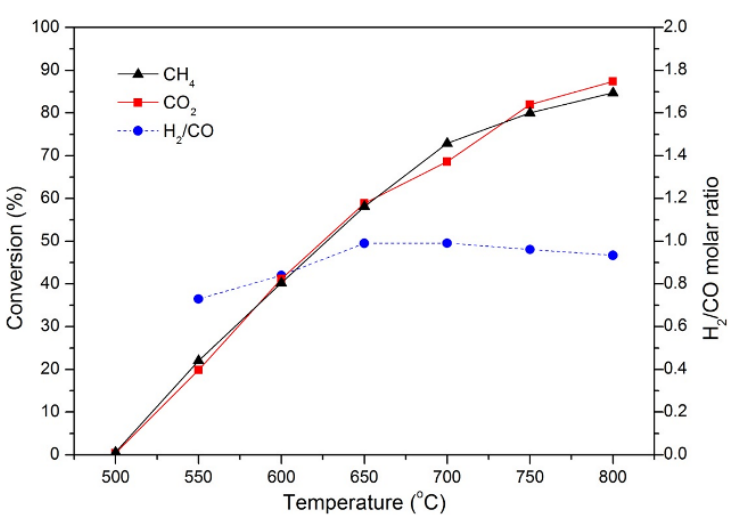

Figure 8. $\left(\mathrm{CH}_{4}, \mathrm{CO}_{2}\right)$ conversions and $\mathrm{H}_{2} / \mathrm{CO}$ molar ratio observed over prepared catalysts during dry reforming of methane as a function of reaction temperature. Reaction conditions: flow rate $\left(\mathrm{Ar}=40 \mathrm{ml} \mathrm{min}^{-1}, \mathrm{CH}_{4}=5 \mathrm{ml} \mathrm{\textrm {min } ^ { - 1 } , \mathrm { CO } _ { 2 } = 5 \mathrm { ml } \mathrm { min }}{ }^{-1}\right) ; 50 \mathrm{mg}$ of reduced catalyst.

\section{Conclusions}

In summary, we synthesized a nickel-based catalyst precursor for dry reforming of methane using a microwave-induced combustion approach. Three types of amino-acids were tested as a fuel: urea, glycine and citric acid. The thermodynamic

\section{References}

1. Belhadi A, Trari M, Rabia C and Cherifi O. Methane steam reforming on supported nickel based catalysts: effect of oxide $\mathrm{ZrO} 2$, La2O3 and nickel composition. Open Journal of Physical Chemistry. 2013; 3:89-96. http://dx.doi.org/10.4236/ ojpc.2013.32011.

2. Larrondo SA, Kodjaian A, Fábregas I, Zimicz MG, Lamas DG, Walsoe de Reca BE, et al. Methane partial oxidation using Ni/ $\mathrm{Ce} 0.9 \mathrm{Zr} 0.1 \mathrm{O} 2$ catalysts. International Journal of Hydrogen Energy. 2008; 33(13):3607-3613. http://dx.doi.org/10.1016/j. ijhydene.2008.04.025.

3. Barros BS, Melo DMA, Libs S and Kiennemann A. CO2 reforming of methane over $\mathrm{La} 2 \mathrm{NiO} 4 / \alpha-\mathrm{A} 12 \mathrm{O} 3$ prepared by microwave assisted self-combustion method. Applied Catalysis modeling of combustion reactions suggest that all tested fuel could assure high adiabatic flame temperature, above $900{ }^{\circ} \mathrm{C}$. However, it was found that the rate of heat release was fuel dependent. While for citric acid, the heat release was too slow drastically limiting the crystallization of the product, the heat release for glycine was too fast, with explosive characteristic. The urea showed an intermediary heat release rate, enough to promote high crystallinity of the product, but without explosive characteristic of the reaction. In all cases, the product was formed as a mixture of phases, including amorphous, but no traces of perovskite-type phases were detected. The as-prepared powders with urea and glycine showed very similar morphology. However, the sample prepared with urea presented a narrow particle size distribution. After calcination at $800{ }^{\circ} \mathrm{C}$ for $4 \mathrm{~h}$, all samples showed the same crystalline composition, only one phase $\mathrm{LaNiO}_{3}$. The sample LNU was used as a catalyst precursor. This sample was reduced in $\mathrm{H}_{2}$ atmosphere to form a Ni $/ \mathrm{La}_{2} \mathrm{O}_{3}$ catalyst which was tested in dry reforming of methane showing high catalytic activity. $\mathrm{CH}_{4}$ and $\mathrm{CO}_{2}$ conversions reached 85 and $88 \%$ at $800{ }^{\circ} \mathrm{C}$, respectively.

\section{Acknowledgements}

The authors are deeply grateful to the Brazilian agencies CAPES and ANP, for the financial support.

A, General. 2010; 378(1):69-75. http://dx.doi.org/10.1016/j. apcata.2010.02.001.

4. Kim TY, Kim SM, Lee WS and Woo SI. Effect and behavior of cerium oxide in $\mathrm{Ni} / \gamma$-Al2O3 catalysts on autothermal reforming of methane: $\mathrm{CeAlO} 3$ formation and its role on activity. International Journal of Hydrogen Energy. 2013; 38(14):6027-6032. http:// dx.doi.org/10.1016/j.ijhydene.2012.12.115.

5. García A, Becerra N, García L, Ojeda I, López E, López $\mathrm{CM}$, et al. Structured Perovskite-based oxides: use in the combined methane reforming. Advances in Chemical Engineering and Science. 2011; 1(04):169-175. http://dx.doi.org/10.4236/ aces.2011.14025.

6. Tristão JC, Pereira MC, Moura FCC, Fabris JD and Lago RM. Controlled reduction of LaFexMnyMozO3/A12O3 composites to produce highly dispersed and stable Fe 0 catalysts: a Mössbauer 
investigation. Materials Research. 2008; 11(2):233-238. http:// dx.doi.org/10.1590/S1516-14392008000200021.

7. Guo J, Lou H, Zhu Y and Zheng X. La-based perovskite precursors preparation and its catalytic activity for $\mathrm{CO} 2$ reforming of CH4. Materials Letters. 2003; 57(28):4450-4455. http://dx.doi.org/10.1016/S0167-577X(03)00341-0.

8. Yang Y, Priya S, Wang YU, Li J-F and Viehland D. Solid-state synthesis of perovskite-spinel nanocomposites. Journal of Materials Chemistry. 2009; 19(28):4998-5002. http://dx.doi. org/10.1039/b903762d.

9. Kambale KR, Kulkarni AR and Venkataramani N. Grain growth kinetics of barium titanate synthesized using conventional solid state reaction route. Ceramics International. 2014; 40(1):667673. http://dx.doi.org/10.1016/j.ceramint.2013.06.053.

10. Madeswaran S, Giridharan NV and Jayavel R. Sol-gel synthesis and property studies of layered perovskite bismuth titanate thin films. Materials Chemistry and Physics. 2003; 80(1):23-28. http://dx.doi.org/10.1016/S0254-0584(02)00489-3.

11. Del Toro R, Hernández P, Díaz Y and Brito JL. Synthesis of $\mathrm{La} 0.8 \mathrm{Sr} 0.2 \mathrm{FeO} 3$ perovskites nanocrystals by Pechini sol-gel method. Materials Letters. 2013; 107(15):231-234. http:// dx.doi.org/10.1016/j.matlet.2013.05.139.

12. Muneeswaran M, Jegatheesan $P$ and Giridharan NV. Synthesis of nanosized $\mathrm{BiFeO} 3$ powders by co-precipitation method. Journal of Experimental Nanoscience. 2013; 8(3):341-346. http://dx.doi.org/10.1080/17458080.2012.685954.

13. Nair SR, Purohit RD, Sinha PK and Tyagi AK. Sr-doped LaCoO3 through acetate-nitrate combustion: Effect of extra oxidant NH4NO3. Journal of Alloys and Compounds. 2009; 477(12):644-647. http://dx.doi.org/10.1016/j.jallcom.2008.10.087.

14. Chandran RG and Patil KC. Combustion synthesis of rare earth cuprates. Materials Research Bulletin. 1992; 27(2):147-154. http://dx.doi.org/10.1016/0025-5408(92)90207-G.

15. Mukasyan AS, Costello C, Sherlock KP, Lafarga D and Varma A. Perovskite membranes by aqueous combustion synthesis: synthesis and properties. Separation and Purification Technology. 2001; 25(1-3):117-126. http://dx.doi.org/10.1016/S13835866(01)00096-X.

16. Najjar H, Lamonier J-F, Mentré O, Giraudon J-M and Batis H. Optimization of the combustion synthesis towards efficient
LaMnO3+y catalysts in methane oxidation. Applied Catalysis B: Environmental. 2011; 106(1-2):149-159. http://dx.doi. org/10.1016/j.apcatb.2011.05.019.

17. Jain SR, Adiga KC and Pai Verneker VR. A new approach to thermochemical calculations of condensed fuel-oxidizer mixtures. Combustion and Flame. 1981; 40:71-79. http://dx.doi. org/10.1016/0010-2180(81)90111-5.

18. Balakrishnan E, Nelson MI and Chen XD. Microwave assisted ignition to achieve combustion synthesis. Journal of Applied Mathematics and Decision Sciences. 2001; 5(3):151-164. http:// dx.doi.org/10.1155/S1173912601000128.

19. Nehru LC and Sanjeeviraja C. Rapid synthesis of nanocrystalline $\mathrm{SnO} 2$ by a microwave-assisted combustion method. Journal of Advanced Ceramics. 2014; 3(3):171-176. http://dx.doi. org/10.1007/s40145-014-0101-5.

20. Lutterotti L. MAUD: Materials Analysis Using Diffraction 2.53. 2015. Available from: $<$ http://www.ing.unitn.it/ $\operatorname{maud} />$. Access in: 27/03/2015.

21. Perry RH and Chilton CH. Chemical engineers handbook (5th ed.). New York: McGraw-Hill; 1973.

22. Dean JA. Lange's handbook of chemistry (12th ed.). New York: McGraw-Hill; 1979.

23. Kingsley JJ and Pederson LR. Combustion synthesis of perovskite LnCrO3 powders using ammonium dichromate. Materials Letters. 1993; 18(1-2):89-96. http://dx.doi.org/10.1016/0167577X(93)90063-4.

24. Gobichon A-E, Auffrédic J-P and Louer D. Thermal decomposition of neutral and basic lanthanum nitrates studied with temperaturedependent powder diffraction and thermogravimetric analysis. Solid State Ionics. 1996; 93(1-2):51-64. http://dx.doi.org/10.1016/ S0167-2738(96)00498-5.

25. Nair MN, Kaliaguine S and Kleitz F. Nanocast LaNiO3 Perovskites as precursors for the preparation of coke-resistant dry reforming catalysts. ACS Catalysis. 2014; 4(11):3837-3846. http://dx.doi.org/10.1021/cs500918c.

26. $\mathrm{Xu} \mathrm{L}$, Song $\mathrm{H}$ and Chou L. One-Pot Synthesis of Ordered Mesoporous $\mathrm{NiO}-\mathrm{CaO}-\mathrm{Al} 2 \mathrm{O} 3$ Composite Oxides for Catalyzing CO2 Reforming of CH4. ACS Catalysis. 2012; 2(7):1331-1342. http://dx.doi.org/10.1021/cs3001072. 